\title{
An Empirical Examination of the Determinants of Private Investment in Nigeria.
}

\author{
MERCY ADA ANYIWE* ROTIMI JOSHUA \\ Department of Economics, Faculty of Social Sciences, University of Benin, Benin City, Nigeria
}

\begin{abstract}
The study investigates the determinants of private investment in Nigeria, employing the Autoregressive Distributed Lag framework on data from 1980 to 2016. In all, the study provides evidence that real gross domestic product, public investment, real interest rate, real exchange rate, credit to private sector and external debt both in a short run and long run significantly affect the level of private investment, except for inflation which was insignificant. Our study revealed that real gross domestic product play an increasingly important role in supporting the nation's growth in private investment. The study recommends that government should give more priorities to expenditures that compliment (crowd in) private investment: such as capital expenditure. Also since previous exchange rate policies are most likely to spur and speedup the growth and development of the domestic industries and also it has the likelihood to increase investment in this sector. Therefore, necessary adjustments need to be effected for the proper positioning of present exchange rate policies to encourage the investors and investment in the domestic economy.
\end{abstract}

Keywords: Private investment, Real Gross Domestic Product, Real Interest Rate, Real Exchange Rate, Credit to Private Sector

DOI: $10.7176 / J E S D / 10-2-11$

\section{Introduction}

Economic growth is the result of a combination of several factors among which is increase in investment (O'Connell and Ndulu, 2000; Veganzones, 2000). Investment is one of the component of aggregate demand, investment has an impact on the level of aggregate demand, and, especially, on the variation of this aggregate demand. Investment is indeed the component of the aggregate demand that oscillates the most, since the other components namely household consumption and public expenditure are relatively stable. Hence a slowdown in investment often translates to a slowdown in economic growth.

Furthermore, since investments consist of accruing production capacity, it influences the productive capacity of the economy and the size of the labour utilized in making this capacity operational. Maintenance of steady growth of investment is a prerequisite factor to long-run growth in the economy (Naa-Idar, Ayentimi, and Frimpong, 2012).

The composition, determinants and impacts of private investment on economic growth in developing countries, have always been a key economic issue that has received considerable attention. Investment is generally classified into four major components: the private domestic investment, the public domestic investment, the foreign direct investment and the portfolio investment. Private domestic investment refers to gross fixed capital formation plus net changes in the level of inventories whereas public investment includes investments by government and public enterprises on social and economic infrastructures, real estate and tangible assets. The combination of private investment and public investment is normally referred to as gross fixed capital formation in order to differentiate them from their counterpart foreign investment. The foreign investment when it is on tangible asset is referred to as direct foreign investment. It is called portfolio investment when it is on shares, bonds, securities and other related financial instruments (Bakare, 2011).

Private investment is a crucial pre-requisite for economic growth because it allows entrepreneurs to set economic activity in motion by bringing resources together to produce goods and services. Rapid and sustained growth is facilitated by steady growth in investment. Entrepreneurship and investment lead to higher productivity, making it possible to invest larger sums in the future. In the course of this process, jobs are created and new technologies are introduced, especially through international trade and investment linkages. Competitive and well-functioning markets are crucial because they promote and reward innovation and diversification, foster firm entry and exit and thus provide a suitable platform for private sector investment. They also have an important role in making the growth process more socially and geographically inclusive, which expands the opportunities for poor people to participate in and benefit from growth. Successful mobilization of private investment is thus increasingly important for creating employment, raising growth rates and reducing poverty. The major economic variable that influences investment whether private or foreign is interest rates (White, 2005). Therefore, economic policy makers in some developing countries have traditionally emphasized on the necessity of keeping interest rates low in order to encourage private sector to invest.

Nigeria, like other developing nations, adopted Structural Adjustment programs (SAP) in 1986 with the aim of correcting macroeconomic misalignments which held sway or was prevalent in the late 1970s. At the core of 
the reforms was the framework for economic restructuring which supports economic diversification away from the country's overdependence on crude oil export to other profitable non-oil sectors of the economy. Despite all the reforms that had been adopted, the country still largely relied on crude oil export revenue for her subsistence thus exposing it to any external shocks that may arise from volatility in the world oil prices (Iyoha, 1998). In the light of this, it is therefore argued that the potentials inherent in domestic private investments that may well serve as an alternative means of boosting the country's economic growth, has not been given adequate attention this provides the motivation for undertaking this study.

It was expected that the Structural Adjustment Programme (SAP) adopted in 1986 should put the Nigerian economy on path of recovery and sustainable development. But despite this structural reform, Nigeria remains confronted with a number of economic maladies. Among these are low level of savings and investment, unprecedented inflationary, as well as high level of unemployment and poverty. Private sector operators argued that the factors which militate against their contributions to the economy include high cost of doing business, unstable macroeconomic policies, infrastructural bottlenecks, faltering consumer spending, lack of capital investment and stifling effect of multiple taxation (Iyoha, 2004). Several studies like (Soludo, 1998, Iyoha, 1998 and Obaseki and Onwioduokit, 1998) suggest that the low productivity and the uncompetitiveness of the private sector in Nigeria can be attributed to the hostile business environment.

Nigeria's economic landscape continues to distort the path to sustainable policy formulation (Soludo, 1998). Rather than for the economy to adjust into recovery, it continues to deteriorate from initial level. The expected role of private sector as an engine of growth was not achieved. The major expansion in private investment needed to sustain economic growth is yet to be achieved.

Nigeria's macroeconomic indicators highlight these poor performances of private investment in Nigeria between 1986 and 2016. For example, private investment declined from 12.3\% of GDP in 1991 to 8.3\% of GDP in 1992. This may partly be due to decreased public investment, which declined over the same period. Private investment then increased to $12.5 \%$ in 1993 and to $16.0 \%$ in 1994 . Thereafter, it declined continuously to $8.9 \%$ in 1996 . The ratio, though increased to $13.0 \%$ in 1999 , but continues to decline reaching its lowest level of $10.7 \%$ in 2000 . Since 2001 , there has been a substantial recovery. Between 2001 and 2005, the ratio average $13.0 \%$; it peaked at $16.2 \%$ in 2002 but declined again to $12.0 \%$ in 2005 and also resulted to a decline to $6.3 \%$ in 2008. Since then there has been a gradual increase in the percent of private investment until 2016 when it declines because of the downturn in economic activities.

In the light of the foregoing, delving deeper into the determinants of domestic private investment behaviour in Nigeria is crucial for understanding how domestic private investment is driven in the country, as this may offer empirical guide for policy formulation.

The major objective of this study is to examine the determinant of private domestic investment in Nigeria.

\section{Review of Related Literature \\ 2.1 Empirical Literature}

There is a finite limit for domestic savings, public investment would in some cases pose a severe constraint for private investment and would crowd out private investment. Balassa (1988) in his study of 30 countries showed the presence of a negative relationship between private investment and public investment. Duncan et al. (1999) is of the opinion that such a negative relationship might not exist in the case of Pacific islands, which have no difficulties accessing foreign savings. The literature is fairly settled on the factors that constrained or otherwise determine private investment. Authors like Greene \& Villanueva (1991); Duncan et al. (1999) have carried out empirical and stochastic investigations on the determinants of private Investment. Most of them discovered that Private investment behaviour is primarily influenced by the profit motive in addition to other factors such as wage rate, real exchange rate policies, and raw material costs, rate of inflation and appropriate pricing of capital, labour and land.

Aside from the factors listed above, private investment would flourish in a supportive environment of cost reductions in power, transport and communications, which are often provided through public investment. For instance, Greene \& Villanueva (1991) carried out an empirical study on 23 countries and found that public investment in physical infrastructure is complementary to private investment. However, as there is a finite limit for domestic savings, public investment would, in some cases, poses a severe constraint for private investment and would crowd out private investment. Balassa (1988) in his study of 30 countries concluded that the presence of a negative relationship between private investment and public investment. In collaborating of these findings, Duncan et al. (1999) pointed out that such a negative relationship might not exist in the case of Pacific Islands, which have no difficulties accessing foreign savings.

According to Duncan et al. (1999), user cost of capital is an important factor in any investment decision by the private sector. When the user cost of capital is increased by raising the cost of bank credit or by increasing the cost of retained earnings, which is the main source of financing investment, there is a decline in investment. Whereas there is a consensus in the literature on the factors discussed so far, findings of various empirical 
studies are not, however, consistent on the relationship between interest rates and investment. While certain studies such as Green \& Villanueva (1991), have confirmed the negative relationship between interest rates and investment, study by others have shown that in repressed financial markets, credit policy affects investment in a distorted manner.

In developing country like Nigeria, private investment is also playing prominent role. Khan and Arshad (2001) attempted to analyse the determinants of private investment by using ARDL cointegration technique to check the existence of long run equilibrium relationship as well as short run dynamics of investment. The results supported the idea of providing suitable environment for markets e.g protection of policy rights, enforcement of contracts and voluntary exchange at market determined prices.

Akpokodje (1998) using a time series data in order to avoid potentially spurious results emanating from non-stationary of the data series. He tried to estimate long run relationship using standard Ordinary Least Squares (OLS) techniques. The long run regression results indicated that a fiscal policy weakened by fiscal deficit has a strong and significant adverse impact on private investment in the long run. The result indicates that a percentage increase in fiscal deficit is capable of contracting private investment by as much as 61 percentage. This negative impact confirms the crowding out effect of government's fiscal deficit programme on private investment in Nigeria.

In the case of Africa, Badawi (2004) investigated the impact of macroeconomic policies on private investment in Sudan employing annual data over the period 1969-1998. The focus was on public investment, credit, devaluation, and interest rate policies while blending cointegration, vector autoregressive (VAR) and error correction techniques to estimate the long and short run coefficients. The results suggested significant crowding-out effect of public investment on private investment in Sudan. Devaluation policies also contributed to discouraging private sector capital expansion. Monetary policy in the form of restricting domestic credit appeared to have had a significant impact on private investment. This was indicated by the positive impact of banking sector credit on private investment. Increasing real interest rates has been impacting negatively on private investment in Sudan.

More recently, Frimpong and Marbuah (2010) sought an empirical assessment of factors that have either stimulated or dampened private sector investment in Ghana. Employing co-integration and error correction techniques within an ARDL framework their results suggest that private investment is determined in the shortrun by public investment, inflation, real interest rate, openness, real exchange rate and a regime of constitutional rule, while real output, inflation, external debt, real interest rate, openness and real exchange rate significantly influenced private investment response in the long-run.

Fowowe (2011) conducted an empirical investigation of the effect of financial sector reforms on private investment in selected Sub-Saharan African countries. An index is developed to track the gradual progress made with implementation of the phases of the reforms. The results of econometric estimations show that financial sector reforms (measured by the index) have had a positive effect on private investment in the selected countries considered for his study, thus offering support to the financial liberalization hypothesis.

Finally, Islam and Wetzel (1991), in a World Bank Study empirically examined the link between real private investment on one hand and real public investment/GDP, corporate tax revenues/GDP, credit to the private sector /GDP, real rate of interest and a dummy for 1976. The dummy for 1976 was included because of the large and unexplained drop in private investment in that 253 year. Employing Ordinary Least Squares (OLS), they find a negative public-private relationship in the case of Ghana thus confirming the findings of Akpalu (2002) but contrast that of Asante (2000) where public investment was found to crowd-in private investment in Ghana. The study also established a positive relationship between corporate tax revenue and flow of credit to the private sector with all the variables having significant coefficients. However, real interest rate was found not have a substantial effect on private investment even though it has the expected negative sign.

\section{Theoretical framework and Methodology \\ 3.1 Theoretical Framework}

The theoretical framework upon which the model is built is the flexible accelerator model, and the neoclassical approach model.

\subsubsection{The Flexible Accelerator Model}

The theories of investment date back to Keynes (1936), who first called attention to the existence of an investment function in an economy. A central feature of the Keynesian analysis is the observation that although savings and investment must be identical ex-post, savings and investment decisions are, in general, taken by different decision makers and there is no reason why ex-ante savings should equal ex-ante investment.

The next phase in the evolution of investment theory gave rise to the accelerator theory, which makes investment a linear proportion of changes in output. In the accelerator model, expectations, profitability and capital costs play no role. Keynesian theory has traditionally favoured the accelerator theory of investment while disregarding the role of factor costs. 
A more general form of the accelerator model is the flexible accelerator model. The basic notion of this model is that the larger the gap between existing and desired capital stock, the greater a firm's rate of investment. The hypothesis is that firms plan to close a fraction, of the gap between the desired capital stock, $\mathrm{K}^{*}$, and the actual capital stock, $\mathrm{K}$, in each period.

This gives rise to a net investment equation of the form of: $I=\boldsymbol{\delta}\left(\mathbf{K}^{*}-\mathbf{K}_{\mathbf{t}}\right)$

Where $\mathrm{I}=$ net investment, $\mathrm{K}^{*}=$ desired capital stock, $\mathrm{K}_{\mathrm{t}}=$ last period's capital stock, and $\delta=$ partial adjustment coefficient.

Asante (2000), explained that within the framework of the flexible accelerator model, output, internal funds, cost of external financing and other variables may be included as determinants of $\mathrm{K}^{*}$. He noted that flexible accelerator mechanism may be transformed into a theory of investment behaviour by adding a specification of $\mathrm{K}^{*}$ and a theory of replacement investment. Alternative econometric models of investment behaviour differ in the determinants of $\mathrm{K}^{*}$, the characterization of the time structure of the investment process and the treatment of replacement investment. In the flexible accelerator model, $\mathrm{K}^{*}$ is proportional to output, but in alternative models, $\mathrm{K}^{*}$ depends on capacity utilization, internal funds, the cost of external finance and other variables.

Mankiw (1992), noted that net investment, depends on the difference between the marginal product of capital and the cost of capital. He further explained that if the marginal product of capital exceeds the cost of capital, firms find it rational to increase capital stock. If the marginal product of capital falls below the cost of capital, firms rather allow to capital stock shrink.

\subsubsection{Neoclassical Approach Model}

Jorgenson (1971) and others have develop the neoclassical approach, which is a version of the flexible accelerator model. In this approach, the desired or optimal capital stock is proportional to output and the user cost of capital (thus depends on the price of capital goods, the real rate of interest, the rate of depreciation and the tax structure). In the "q" theory of investment (which is also in the neoclassical framework) associated with Tobin (1969), the ratio of the market value of the existing capital stock to its replacement cost (the "q" ratio) as the main force driving decision to raise investment. Tobin argues that delivery lags and increasing marginal cost of investment are the reasons why q would differ from unity.

\subsubsection{Neoliberal School of Thought}

Another approach known as "neoliberal" emphasizes the importance of financial deepening and high interest rates in stimulating growth. The proponents of this approach are McKinnon (1973). The core of his argument rests on the claim that developing countries suffer from financial repression. Financial repression in the deliberate holding of interest rate well below market determined level. McKinnon believe that if these countries liberate these repressive conditions, it would induce savings, boost investment and stimulate economic growth. Not only will liberalization increase savings and loanable funds, it will result in a more efficient allocation of these funds, both contributing to a higher economic growth.

In the neoliberal view, investment is positively related to the real rate of interest in contrast with the neoclassical theory. The reason for this is that a rise in interest rates increases the volume of financial savings through financial intermediaries and thereby raises investible funds, a phenomenon that McKinnon (1973) calls the "conduit effect". Thus, while it may be true that demand for investment declines with the rise in the real rate of interest, realized investment actually increases because of the greater availability of funds. This conclusion applies only when the capital market is in disequilibrium with the demand for funds exceeding supply.

It is clear from the discussion in this section that private investment depends on three broad categories of variables: Keynesian, neoclassical, and uncertainty variables. Variables that may be included in the Keynesian tradition include growth rate of GDP, internal funds and capacity utilization. The neoclassical determinants of private investment include Tobin's q, real interest rate, user cost of capital and public investment ratio. There are three uncertainty variables. The first is variability (variance, moving standard deviation or moving coefficient of variation) of the user cost of capital, real exchange rate, inflation rate, distortions in the foreign exchange.

\subsection{Model Specification}

In an attempt to empirically examine the composition and determinants of private investment in Nigeria, 19802016. Based on the above theoretical framework for this study, we specified the model as follows:

\section{PRINV = f (RGDP, PUBINV, INFL, RIR, REXR, CRPS, EXDEBT)}

Where,

PRINV = Private Capital Investment (proxy for private investment)

RGDP = Real Gross Domestic Product (proxy for demand conditions in the economy);

PUBINV $=$ Domestic Investment (proxy for Pubic Investment)

INFL $=$ Rate of inflation (proxy for macroeconomic uncertainties/instability);

RIR = Real Interest Rate (proxy for User Cost of Capital);

REXR=Real Exchange Rate; 
CRPS $=$ Credit to Private Sector (proxy for liquidity constraint),

EXDEBT $=$ External Debt.

Expressing equation 2 in a linear form we have;

PRINV $=\beta_{0}+\beta_{1}$ RGDP $+\beta_{2}$ PUBINV $+\beta_{3}$ INFL $+\beta_{4}$ RIR $+\beta_{5}$ REXR $+\beta_{6}$ CRPS + $\beta_{7} \operatorname{lnEXDEBT}$

Econometrically, to include the random error term, the explicit econometric model is formulated as:

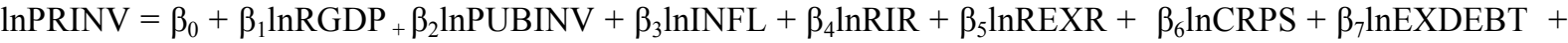
$\mu \mathrm{i}$

\subsection{A Prior Expectations.}

$(\boldsymbol{\beta 1}>\mathbf{0})$.

Domestic Investment Proxy for Pubic Investment. Public (government) investment has an ambiguous a priori effect on private investment. On one hand, studies by Rossiter (2002) and other researchers report a negative effect of public investment on private investment. Public investment may crowd-out private investment via increased deficits and a high interest rate and the competition for scarce resources. However, evidence of a complementarity between public and private saving has been found by studies such as Blejer and Khan (1984), Aschauer (1989), and Greene and Villanueva (1991). Public investment may act as crowding-in catalyst through the provision of key infrastructure (e.g. transport, communication, irrigation projects, etc). Thus, the effect of public investment on private investment could be: $\boldsymbol{\beta} \mathbf{2}<\mathbf{0}$ implying crowding-out effect, whereas $\boldsymbol{\beta} 2>\mathbf{0}$ suggesting crowding-in effect of public investment.

A high inflation rate is expected to negatively affect private investment. Therefore, the study expects the coefficient to be negative $(\boldsymbol{\beta 3}<\mathbf{0})$.

The effect of real interest rate on private investment in developing countries is ambiguous. Under the neoclassical investment model, real interest rate is treated as a key component of the user cost of capital and therefore affects private investment negatively. However, there is also the argument that a higher real interest rate increases the flow of bank credits, which complements the private sector savings and facilitates private capital formation, and hence private investment. Thus, a negative coefficient of real interest rate $(\boldsymbol{\beta} 4<0)$ will imply user cost of capital effect whereas a positive $(\boldsymbol{\beta 4}>\mathbf{0})$ one would support the complementarity hypothesis.

The real exchange rate can influence the level of private-sector investment, as it is one of the components that determine the real cost of imports. The effect of the real exchange rate on private investment is ambiguous. Chibber and Mansoor (1990) argue that a real depreciation acts as an adverse supply shock in the - production of investment goods. A currency devaluation increases the real cost of purchasing imported capital goods, thereby reducing the profitability of the private sector and possibly causing investment to decline.

Furthermore, a real devaluation can mean a fall in the real income of the economy as a whole, thus reducing productive capacity and activity to levels that businesses find uncomfortably low. Conversely, real currency devaluation can have a positive impact on investment in sectors producing internationally traded goods, as it increases competitiveness and export volumes.

Similarly, real exchange rate depreciation increases profitability in export oriented sectors and therefore promotes investment in these sectors. On the other hand, depreciation of the exchange rate increases the cost of imported capital goods, and thus decreases investment in import dependent production sectors. Thus the effect of real exchange rate on private investment (i.e. $\beta 5$ ) is also ambiguous. Thus the sign of real exchange rate parameter could be positive or negative i.e $\mathbf{\beta 5}>0$ or $\boldsymbol{\beta 5}<0$

Increasing credit by the banking sector to the private sector is likely to boost private sector investment. Thus credit to the private sector coefficient to be positive that is $\boldsymbol{\beta 6} \mathbf{0} \mathbf{0}$

The existence of a debt overhang may inhibit investment in many indebted countries because the possibility that confiscatory future taxation could be used to finance future debt service, which leaves few investible funds in the domestic economy and may affect the behaviour of private investors. Thus, a large external debt-to-GDP ratio is likely to have a negative impact on private investment. The coefficient of external debt is expected to be negative $(\boldsymbol{\beta 7}<\mathbf{0})$ for Nigeria.

\subsection{Estimation Technique}

This study employs the Autoregressive Distributed Lag (ARDL) method proposed by Pesaran, Shin and Smith (2001) to examine the determinant of private investment in Nigeria. ARDL is employed for certain advantages. First, it can be applied irrespective of whether the underlying variables are I(1), I(0) or a combination of both. Secondly, unlike the Engle and Granger and Johansen multivariate cointegration approach, it is not sensitive to the values of nuisance parameters in finite sample thereby making its small sample properties superior. Thirdly, the error correction model (ECM) can be derived from ARDL through a simple linear transformation, which integrates short run adjustments with long run equilibrium without losing long run information. Also, the ARDL approach is known for providing unbiased long run estimates even when some of the variables are endogenous 
(Adom, Bekoe, Akoena, 2012; Pahlavani, Wilson and Worthington, 2005).

Prior to the ARDL estimation, we carry out unit root test on all the variables employing the Augmented Dickey Fuller (ADF) test to account for the stationarity of the variables and establish the order of integration.

\section{Presentation and Interpretation of Empirical Results}

\subsection{Unit Root Test}

The result from the Augmented Dickey-Fuller unit root test shows that all the variables were found to be stationary at first difference except for real gross domestic product and inflation rate which were stationary at levels. The null hypothesis of non-stationarity is therefore rejected. Given that some of the variables were not stationary at their levels form, a co-integration test is then conducted using the Johansen co-integration test to determine if there exist a long term equilibrium relationship between the variables.

Table 1: Unit Root Test Result

\begin{tabular}{|l|c|c|c|c|}
\hline VARIABLE & $\begin{array}{c}\text { ADF } \\
\text { STATISTIC }\end{array}$ & $\begin{array}{c}\text { 0.05 CRITICAL } \\
\text { VALUE }\end{array}$ & $\begin{array}{c}\text { ORDER OF } \\
\text { INTEGRATION }\end{array}$ & REMARKS \\
\hline LPRINV & -5.488594 & -2.963972 & $\mathrm{I}(1)$ & STATIONARY \\
\hline LRGDP & -4.486276 & -2.960411 & $\mathrm{I}(0)$ & STATIONARY \\
\hline LPUBINV & -8.588333 & -2.963972 & $\mathrm{I}(1)$ & STATIONARY \\
\hline LINF & -4.737273 & -2.960411 & $\mathrm{I}(0)$ & STATIONARY \\
\hline LRIR & -7.953543 & -2.963972 & $\mathrm{I}(1)$ & STATIONARY \\
\hline LREXR & -4.779533 & -2.963972 & $\mathrm{I}(1)$ & STATIONARY \\
\hline LCRPS & -4.020559 & -2.963972 & $\mathrm{I}(1)$ & STATIONARY \\
\hline LEXDEBT & -3.88171 & -2.963972 & $\mathrm{I}(1)$ & STATIONARY \\
\hline
\end{tabular}

Source: Author's computation, 2018

\subsection{Johansen Co-Integration Test}

The result of the co-integration test shows that both the trace statistic and maximum eigen value statistic confirm the existence of co-integrating equations among the variables of interest. This proves that there exist a long run equilibrium relationship between the variables. Since the variables are co-integrated, this satisfies the convergence property. Therefore, an error correction model is then presented to integrate both the long run and short run dynamics.

Table 2: Co-integration test result

\begin{tabular}{|l|c|c|c|c|c|}
\hline $\begin{array}{c}\text { Hypothesized } \\
\text { no of CE(s) }\end{array}$ & Eigenvalue & Trace statistic & $\begin{array}{c}\text { 0.05 critical } \\
\text { value }\end{array}$ & $\begin{array}{c}\text { Max-Eigen } \\
\text { statistic }\end{array}$ & $\begin{array}{c}\text { 0.05 critical } \\
\text { value }\end{array}$ \\
\hline None & 0.918772 & 230.7529 & 143.6691 & 75.31477 & 48.87720 \\
\hline At most 1 & 0.837275 & 155.4381 & 111.7805 & 54.47074 & 42.77219 \\
\hline At most 2 & 0.657962 & 100.9674 & 83.93712 & 32.18500 & 36.63019 \\
\hline At most 3 & 0.572588 & 68.78238 & 60.06141 & 25.50020 & 30.43961 \\
\hline At most 4 & 0.496004 & 43.28219 & 40.17493 & 20.55559 & 24.15921 \\
\hline At most 5 & 0.369856 & 22.72660 & 24.27596 & 13.85422 & 17.79730 \\
\hline At most 6 & 0.171746 & 8.872383 & 12.32090 & 5.653074 & 11.22480 \\
\hline At most 7 & 0.101753 & 3.219310 & 4.129906 & 3.219310 & 4.129906 \\
\hline
\end{tabular}

Source: Author's computation, 2018 
4.3 Estimated Dynamic Short run Coefficients

Table 3: Error Correction Representation for the Selected ARDL Model Dependent Variable: D(LGDP)

\begin{tabular}{|c|r|r|r|r|}
\hline Variable & Coefficient & Std Error & \multicolumn{1}{l|}{ t-Statistic } & Prob. \\
\hline DLRGDP & 0.706397 & 0.841517 & 0.839434 & 0.4164 \\
\hline DLPUBINV & 3.377513 & 1.235136 & $2.734527 * *$ & 0.0357 \\
\hline DLINF & -0.057061 & 0.026431 & $-2.158866^{* *}$ & 0.0462 \\
\hline DLINF(-1) & 0.223444 & 0.205708 & 1.086220 & 0.2971 \\
\hline DLINF(-2) & 0.104808 & 0.289024 & 0.362628 & 0.7227 \\
\hline DLRIR & 0.051997 & 0.204975 & 0.253673 & 0.8037 \\
\hline DLRIR(-1) & -0.184651 & 0.058913 & $-3.134299 * *$ & 0.0140 \\
\hline DLREXR & 0.511232 & 1.315644 & 0.388579 & 0.7039 \\
\hline DLREXR(-1) & 1.192824 & 1.051619 & 1.134274 & 0.2772 \\
\hline DLCRPS & 2.525004 & 0.999696 & $2.525772 * *$ & 0.0253 \\
\hline DLCRPS(-1) & 1.208846 & 0.329747 & $3.665983 * *$ & 0.0171 \\
\hline DLEXDEBT & -3.036212 & 2.070331 & -1.466535 & 0.1663 \\
\hline DLEXDEBT(-1) & -1.201448 & 0.672425 & $-1.786739 * *$ & 0.0973 \\
\hline DLEXDEBT(-2) & 0.690224 & 0.575236 & 1.199897 & 0.2516 \\
\hline ECM1(-1) & -0.641085 & 0.596967 & $-3.073903 * *$ & 0.0024 \\
\hline R-squared & -0.527064 & 0.237695 & $-2.217399 * *$ & 0.0450 \\
\hline F-statistic & 0.68 & Adjusted & 0.62 & \\
\hline Durbin-Watson statistic & 1.73 & R-squared & & \\
\hline F-stat Prob. & 0.027992 & \\
\hline
\end{tabular}

Values: ** and *** indicates significance at the $5 \%$ level and $10 \%$ respectively.

Sources: Authors' computation, 2018

Table 3 presents the error correction model. The result shows that real gross domestic product positively impact on private investment. This is in conformity with the a priori expectation. The result shows that a one percent increase in real gross domestic product will lead to about 3.4 percent increase in private investment. It can also be seen that real gross product is statistically significant at $5 \%$ significance level in explaining private investment dynamics.

Public investment on the other hand, was seen to negatively impact private investment. This is in conformity with the a priori expectation. As seen from the result, an increase in public investment by one percent would lead to a decrease in private investment by about -0.06 percent. This conforms and explains the crowding out effect of public investment on private investment.

The results shows that inflation rate (DLINF) impacts on the level of private investment positively. The result shows that an increase in inflation would lead to an increase in private investment by about 0.2 percent. This is seen as a paradox because inflation rate negates the a priori expectation. The $t$-statistic of inflation rate shows that the variable is not statistically significant in explaining the changes that occur in private investment.

Real interest rate (DLRIR) is seen to impact private investment negatively and significantly. It can be seen that an increase in real interest rate by one percent would lead to a decrease in the level of private investment by about -0.18 percent. This is in conformity to a priori expectation as increase in cost of goods will likely reduce demand and hence volume of private investment..

Exchange rate (DLEXC) is seen to impact private investment positively. An increase in exchange rate by one percent as seen from the result will bring about 2.5 percent increase in private investment. The t-test shows that the variable became statistically significant at the $5 \%$ significance level after lagging it by one year.

Credit to private sector is seen to have a positive impact on private investment. The result shows that an increase in credit to private sector by one percent would lead to an increase in private investment by about 1.2 percent. The test for significance reveals that the variable is statistically significant at the $5 \%$ significance level in explaining changes that occur in private investment.

External debt (DLEX) is seen to impact private investment negatively. A cursory look at the result shows that the variable is significant in explaining what happens to private investment. From the result, it can be seen that an increase in the level of external debt by one percent would bring about a 0.64 percent decrease in private investment.

One remarkable feature to notice is the coefficient of the parameter of the error correction term. The coefficient of the error correction model $(\mathrm{ECM})_{-1}$ shows that speed of adjustment from short-run disequilibrium to long-run equilibrium. From Table 5, the $\mathrm{ECM}_{(-1)}$ has a coefficient of -0.527064 and its t- value of -2.217399 . The coefficient of the error term carries the correct sign and it is significant at the $5 \%$ level of significance. The 
coefficient reveals $52 \%$ of past year's deviation from equilibrium in the short run to correct in the long. More so, since the $\mathrm{ECM}_{(-1)}$ has the negative sign, it therefore show that about half of the difference between the long run equilibrium and short run.

The diagnostic test of the result reveal that the overall fit is satisfactory with an R-bar squared of 0.622810. It indicates that more than $62 \%$ variance in the dependent variable is explained by the independent variables taken together. The remaining $38 \%$ can be attributed to variables like political instability, saving, foreign capital flows e.t.c. which are not included in the model.

The F- statistics of 11.88982 and probability of 0.02 shows that the overall model is statistically significant even at $1 \%$ significance level. Hence the model put together is highly significant and impressive.

In addition, the DW-Statistic which is a measure of the presence of auto correlation in a model was noticed to be free from autocorrelation, since the DW statistics observed in the model is 1.737322 which is approximately 2 . This means that the model is reliable in explaining determinant of private investment in Nigeria.

\subsection{Policy Implication}

On the policy front, the study highlights important key policy-related macroeconomic variables that have had significant impacts on private capital formation in Nigeria over the study period. Empirical findings obtained in the long-run showed that there is no doubt that growth in real output or aggregate demand conditions is the engine of private sector investment growth in Nigeria. Improving the productive sectors such as, agriculture and manufacturing, could go a long way to increase private investment levels and growth in output.

The study shows that private investment and public investment are not complementary using Nigeria data obtained. Rather, public investment crowds out private domestic investment in Nigeria. This indicated that poor infrastructure has been a problem and remains a problem for domestic private investment. Individual components of macroeconomic instability and political instability were found to be inhibitors to private Investment. However, the overall measures were identified as a major hindrance to private investment. This reveals a poor investment climate and its detrimental effect on private investment. Thus, the investment climate constitutes a bad indicator for current investment decisions.

Macroeconomic instability like inflation and real exchange rate were found to be insignificant. However, the overall measure was identified as a major hindrance to private investment both in the time series analysis and in the study. The results suggest that policies that address only some components of macroeconomic instability may not be enough to improve private investment. For policies to improve private sector response must be addressed.

Interest rate is an important variable in explaining variation in private investment. It coefficient show a negative value and statistically significant. This implies that interest rate must be structured in an efficient way that does not distort private investment.

The growth of real credit to the private sector had a positive and statistically significant effect on private investment. This is strongly supported by the study results, and suggests that credit has been a problem and remains a problem for private investment. The question of finance must therefore be addressed in order to ensure continuing participation of the private sector in investment.

Finally, the external debt stock coefficient was found to be negative and statistically significant. The implication of this is that the external debt stock affect investment mainly through the "debt overhang" effect, the "crowding out" effect and credit rationing process/ mechanism.

\section{Findings, Policy Recommendations and Conclusions 5.1 Summary of Findings}

The aim study was to investigate econometrically, the composition and determinants of private investment in Nigeria. In the model private investment was a function of Real gross domestic product, public investment, inflation, real interest rate, exchange rate, credit to private sector and external debt. The study employed stationarity, co- integration and error correction mechanism. Our study revealed that real gross domestic product play an increasingly important role in supporting the nation's growth in private investment. The co integration and error correction mechanism of regression was adopted and we came up with the following findings:

$>$ Real gross domestic product was found to be positive and highly significant.

$>$ Public investment has a negative impact of private investment.

$>$ Inflation had a positive impact on private investment but it had no significance to private investment

$>$ Interest rate had a negative impact on private investment.

$>$ Exchange rate had a positive impact on private investment

$>$ Credit to private sector had a positive impact on private investment

$>$ External debt had a negative impact on private investment. 


\subsection{Policy Recommendations}

The following policy recommendations are outcomes of the findings of the study;

1. Government should give more priorities to expenditures that compliment (crowd in) private investment: such as capital expenditure, capital expenditure on administration, recurrent expenditure on economic services, and recurrent expenditure on transfer services rather than spending on expenditures that substitute for private investment (crowd out) effect on private investment: such as expenditures on recurrent expenditure, recurrent expenditure on administration, recurrent expenditure on social and community services, capital expenditure on transfer, capital expenditure on economic services and capital expenditure on social and community services.

2. Since previous exchange rate policies are most likely to spur and speedup the growth and development of the domestic industries and also it has the likelihood to increase investment in this sector. Therefore, necessary adjustments need to be effected for the proper positioning of present exchange rate policies to encourage the investors and investment in the domestic economy.

3. Furthermore, in view of the nature of Nigeria economy epitomized by the problems hindering private investment like high government expenditure and deficit financing, the government should be maintain it expenditure profile that has direct impact on the private sector.

4. Further, government should ensure efficient delivery of services and increased productivity of public investment. Efforts such as privatization of SOEs should be pursued to ensure significant long-run growth of the private sector.

5. Despite the lapses in Nigeria economic, the government expenditure, deficit financing and high external debt burden explain low investment profile in Nigeria, and government should redirect it fiscal policy that would favor the private investor by discouraging high government expenditure and maintaining low fiscal deficit

6. A weak currency contributes to macroeconomic instability, a factor identified as a major hindrance to private investments. This fact demands that monetary authorities in Nigeria should endeavour to ensure the stability of the Naira against major currencies. Such policy direction will engender positive response from the private sector.

7. If the private sector is to stimulate economic growth. The need for the government to continue to develop the infrastructural base of the economy to boost the private sector participation cannot be over emphasised.

8. Finally, the government is also advised to create a conducive environment that will attract domestic and foreign investor. It would also be beneficial to increase the capacity of local firms to respond to new investment opportunities and to expand business relationship with foreign investors.

\subsection{Conclusion}

The main aim of this paper was to investigate the composition and determinants of private investment within the context of Nigeria over the period 1980-2011. The specific objective was to identify the determinants and their respective nature of relationship with private investment both in the short run and long run perspectives. The study employed the techniques of co-integration and error correction technique which provided mechanisms to deal with the problems of unit root faced in time series data. In all, the study provides evidence that real gross domestic product, public investment, real interest rate, real exchange rate, credit to private sector and external debt both in a short run and long run significantly affect the level of private investment, except for inflation which was insignificant.

Applying the general to specific approach to error correction model, statistical results suggested the existence of stable long run co-integrating relationships between macroeconomic and other variables and private investment. Overall, variables that affect private investment are consistent with most of the hypothesised signs and are also found to be statistically significant.

\section{BIBLIOGRAPHY}

Adom, P.K., Bekoe, W., \& Akoena, S.K., (2012). "Modelling aggregate domestic electricity demand in Ghana: An autoregressive distributed lag bounds cointegration approach". Energy Policy, 42; 530 - 537.

Akpalu, W., (2002) "Modelling Private Investment in Ghana: An Empirical Time Series Econometrics Investigation (1970-1994)," The Oguaa Journal of Social Sciences, Vol. 4.

Akpokodje, G. (1998) "Macroeconomic Policies and Private Investment in Nigeria, Rekindling Investment for Economic Development in Nigeria," Proceedings of the Annual Conference of the Nigerian Economic Society, 59-74.

Asante, Y. (2000) "Determinants of Private Investment Behaviour". AERC Research Paper No. 100, Nairobi: AERC.

Aschauer, D. A. (1989) “Does Public Capital Crowd-out Private Capital?” Journal of Monetary Economics, 24, 
pp. 171-88.

Badawi, A., (2004) "Private Capital Formation and Macroeconomic Policies in Sudan: Application of a Simple Cointegrated Vector Autoregressive Model," Department of Economics, University of Khartoum.

Bakare, A. S. (2011) “The Determinants of Private Domestic Investment in Nigeria." Far East Journal of Psychology and Business, 4 (2)

Balassa, B. (1988) "Public Finance and Economic Development," PPR Working Paper No.31, World Bank, Washington, D. C.

Blejer, M. \& Khan, M. (1984). Government policy and private investment in developing countries. IMF Staff Papers, 31, (2).

CBN 2016, Central Bank of Nigerian Statistical Bulletin, Central Bank of Nigeria Publication, 31st December 2016.

Chibber, A. \& Mansoor, D. (1990), "Fiscal policy and private investment in developing countries," Recherche Economique, XLIV, Numero 2-3.

Duncan, R., Cuthbertson, S. \& Bosworth M. (1999) "Pursuing Economic Reform in the Pacific," Pacific Studies Series No.18, Asian Development Bank, Manila.

Engle, R., \& Granger, C. (1987) "Cointegration and error correction representation: estimation and testing," Econometerica, 55, 251-276. http://dx.doi.org/10.2307/1913236.

Fowowe, B. (2011) "Financial Sector Reforms and Private Investment in sub-Saharan African countries," Journal of Economic Development 79, 36(3).

Frimpong, J. M., \& Marbuah, G. (2010) "The Determinants of Private Sector Investment in Ghana: An ARDL Approach," European Journal of Social Sciences, 15(2).

Greene, J. \& D. Villanueva (1991) "Private Investment in Developing Countries: An Empirical Analysis," IMF Staff Papers, 38 (1),

Islam, R., \& Wetzel, D.L. (1991) "The Macroeconomics of Public Sector Deficits: The Case of Ghana," Country Economics Department Working Papers, No. 672, World Bank.

Iyoha, M. A. (1998) "Rekindling Investment for Economic Development in Nigeria: The Macroeconomic Issues. In: Ben A. Aigbokhan, ed: Rekindling Investment for Economic Development in Nigeria," The Nigeria Economic Society, Ibadan, pp 4-35

Iyoha, M. A. (2004) “Macroeconomics Theory and Policy,” Revised Edition. MINDEX Publishing, Benin City, Nigeria.

Jorgenson, D.W. (1971) "Econometric Studies of Investment Behaviour: A Survey," Journal of Economic Literature, Vol. 9(4). pp 111-147

Keynes, J. M. (1936) “The General Theory Employment, Interest and Money” London Macmillan.

Khan, S. \& Arshad, M. (2001) "What determines Private Investment', A case of Pakistan," The Pakistan Institute of Development Economics, working paper no. 36.

Mankiw, M. Gregory, (1992) Macro Economics fifth edition. London: Worth publishers.

McKinnon, R. I. (1973) Money and Capital in Economic Development. Washington DC: The Brookings Institution.

McKinnon, R. I. (1973). Money and Capital in Economic Development. Washington DC: The Brookings Institution.

Naa-Idar, F., Ayentimi, D. T., \& Frimpong, J. M. (2012). Time Series Analysis of Determinants of Private Investment in Ghana (1960-2010). Journal of Economics and Sustainable Development, Vol. 3, No. 13.

Obaseki, P. J. \& E. A. Onwioduokit (1998) "Public and Private Investment and Economic Growth: Evidence from Nigeria. In: Ben A. Aigbokhan, ed: Rekindling Investment for Economic Development in Nigeria," The Nigerian Economic Society, Ibadan, pp 365-382.

O’Connell, S.A. \& Ndulu B.J. (2000) “Africa's growth experience: A focus on sources of growth”. Framework paper prepared for the AERC Collaborative Research Project on Explaining African Economic Growth Performance, p. 53 African Economic Research Consortium, Nairobi.

Oshikoya, W. T. (1994) "Macroeconomic Determinants of Domestic Private Investment in Africa: An Empirical Analysis", Economic Development and Cultural Change, 42 (3), pp. 573-596.

Pahlavani, M., Wilson, E. \& Worthington, A. C. (2005) "Trade-GDP Nexus in Iran: An Application of the Autoregressive Distributed Lag (ARDL) Model”. American Journal of Applied Sciences, Vol. 2 (7); 11581165 .

Pesaran, M.H., Shin, Y. \& Smith, R. J. (2001) "Bounds testing approaches to the analysis of level relationships". Journal of Applied Econometrics, 16; 289-326.

Rossiter, R. (2002) "Structural Co-integration Analysis of Private and Public Investment" International Journal of Business and Economics, 1 (1), pp. 59-67.

Soludo, C. (1998) "Investment in the Growth Process: A Measures of the Economists Ignorance in Africa. In: Ben Aigbokhan, ed: Rekindling Investment for Economic Development in Nigeria," The Nigerian 
Economic Society, Ibadan, pp.3-34.

Tobin, J. (1969) "A General Equilibrium Approach to Monetary Theory," Journal of Money, Credit and Banking, 1(1), 15-29. http://dx.doi.org/10.2307/ 1991374

Veganzones, M.A. 2000. "Infrastructures, investissement et croissance: Un bilan de dix ans de recherche'. Etudes et Documents No. 2000/7, CERDI.

White, S. (2005) "Enhancing private investment for development: Policy guidance for development agencies. 